INOBIS: Jurnal Inovasi Bisnis dan Manajemen Indonesia

Volume 1, Nomor 4, September 2018

Misti Hariasih; Rizal Yulianto; Amrin Hidayat

\title{
Pengaruh Risiko Kredit dan Efisiensi Operasional terhadap Kinerja BPR Konvensional
}

\author{
Misti Hariasih, Rizal Yulianto, Amrin Hidayat \\ (Fakultas Ekonomi dan Bisnis Universitas Muhammadiyah Sidoarjo \\ Email : mistihariasih@umsida.ac.id
}

\begin{abstract}
Abstrak
Tujuan dari penelitian ini yaitu untuk mengetahui pengaruh risiko kredit (NPL) dan Efisiensi operasional (BOPO) secara simultan terhadap kinerja keuangan bpr konvensional, untuk mengetahui pengaruh risiko kredit (NPL) secara parsial terhadap kinerja keuangan bpr konvensional, dan untuk mengetahui pengaruh efisiensi operasional (BOPO) secara parsial terhadap kinerja keuangan bpr konvensional. Penelitian ini menggunakan pendekatan analisis kuantitatif deskriptif dengan teknik analisis regresi linier berganda dan menggunakan program SPSS versi 16 for windows. Hasil penelitian ini menunjukkan bahwa secara parsial variabel risiko kredit (X1) berpengaruh secara signifikan negatif terhadap kinerja keuangan bpr konvensional (Y), sedangkan variabel efisiensi operasional (X2) secara parsial tidak berpengaruh terhadap kinerja keungan bpr konvensional (Y). Dan hasil uji secara simultan atau bersamabersama, variabel risiko kredit (X1) dan efisiensi operasional (X2) berpengaruh secara signifikan terhadap kinerja keuangan bpr konvensional (Y), hal ini dibuktikan dengan hasil uji $\mathrm{F}$ dengan nilai sebesar sig $0,000<0.05$.
\end{abstract}

Kata-kata kunci: risiko kredit (non performing loan), efisiensi operasional (Bopo) dan kinerja keuangan (return on assets)

\section{Pendahuluan}

Perbankan mengemban fungsi utama yaitu untuk menghimpun dana dari masyarakat dalam berbagai bentuk simpanan yang kemudian dana tersebut disalurkan kembali berbentuk pemberian kredit kepada pihak-pihak yang membutuhkan, serta memberikan pelayanan jasa kepada masyarakat. Semakin berkembang kehidupan masyarakat dan transaksi-transaksi perekonomian suatu negara, maka akan membutuhkan pula peningkatan peran sektor perbankan melalui pengembangan produk-produk jasanya. (Hempel, 1994 dalam Bachruddin, 2006).

Krisis yang di alami di Indonesia yang terjadi sejak tahun 1997 berawal dari krisis moneter dimana nilai tukar rupiah terhadap dolar amerika serikat sangat lemah yang mengakibatkan hancurnya sendi-sendi ekonomi termasuk sektor perbankan dan merosotnya kepercayaan masyarakat kepada lembaga perbankan. Akibatnya bank lumpuh dihantam krisis kredit macet.

Risiko kredit atau kredit macet dapat diukur dengan menggunakan Non Performing Loan (NPL). NPL mencerminkan besarnya kredit yang bermasalah atau biasa disebut kredit macet. Jika NPL tinggi, maka besarnya kredit bermasalah lebih besar dibandingkan kredit yang diberikan kepada debitur. Jika potensi tidak terbayarnya hutang semakin tinggi, maka beban operasional akan meningkat. Peningkatan beban operasional akan menurunkan laba dan membuat bank menjadi tidak efisien. Efisiensi operasional suatu bank dapat diukur dengan menggunakan rasio BOPO. Semakin rendah BOPO berarti semakin efisien bank tersebut dalam mengendalikan beban operasionalnya, maka keuntungan yang diperoleh bank akan semakin 
INOBIS: Jurnal Inovasi Bisnis dan Manajemen Indonesia

Volume 1, Nomor 4, September 2018

Misti Hariasih; Rizal Yulianto; Amrin Hidayat

besar. Berdasarkan uaraian tersebut, tujuan dari penelitian ini yaitu untuk mengetahui pengaruh risiko kredit dan efisiensi operasional terhadap kinerja bpr konvensional

\section{Landasan Teoritis}

\section{Risiko Kredit}

Berdasarkan Peraturan Bank Indonesia No. 11/25/PBI/2009, risiko kredit adalah risiko akibat kegagalan debitur dan/atau pihak lain dalam memenuhi kewajiban kepada bank. Jika kewajiban nasabah terhadap bank pada saat jatuh tempo tidak terpenuhi, maka bank akan menghadapi risiko kredit. Resiko kredit dapat timbul karena beberapa hal sebagai berikut:

1. Adanya kemungkinan pinjaman yang diberikan oleh bank atau obligasi (surat hutang) yang dibeli oleh bank tidak terbayar.

2. Tidak terpenuhinya kewajiban dimana bank terlibat di dalamnya bisa melalui pihak lain, misal: kegagalan memenuhi kewajiban pada kontrak derivatif.

Resiko kredit merupakan risiko yang paling signifikan dari semua risiko yang menyebabkan kerugian potensial. Risiko kredit adalah risiko yang terjadi karena kegagalan debitur, yang menyebabkan tak terpenuhinya kewajiban untuk membayar hutang. Secara garis besar, risiko kredit dapat dibagi menjadi 3 (tiga): risiko default, risiko exposure dan risiko recovery. Risiko kredit dapat bersumber dari berbagai aktivitas Bank, antara lain: pemberian kredit, transaksi derivatif, perdagangan instrument keuangan, serta aktivitas Bank yang lain, termasuk yang tercatat dalam banking book maupun trading book.

\section{Efisiensi Operasional}

Riyadi (2006:141), menyatakan bahwa Efisiensi operasional merupakan masalah yang kompleks di mana setiap perusahan perbankan selalu berusaha untuk memberikan layanan yang terbaik kepada nasabah, namun pada saat yang sama bank harus berupaya untuk beroperasi dengan efisien. Kompetisi di industri perbankan bagaimanapun juga dapat menurunkan tingkat profitabilitas masing-masing bank, dan apabila tingkat profitabilitas ini rendah maka akan dapat mengakibatkan bank akan mengalami kerugian yang cukup berarti dan ini tentunya dapat mengancam kelangsungan hidup usaha perbankan. Indikator efisiensi operasional yang lazim digunakan adalah BOPO (rasio biaya operasional dengan pendapatan operasional).

\section{Kinerja Keuangan BPR}

Menurut Abdullah (2004:108) "Kinerja keuangan bpr adalah gambaran kondisi keuangan pada suatu periode tertentu baik menyangkut aspek penghimpunan dana maupun penyaluran dana yang biasanya diukur dengan indikator kecukupan modal, likuiditas dan profitabilias bpr. Laporan keuangan merupakan alat untuk berkomunikasi anatara data keuangan dengan pihak pihak yang berkepentingan dengan data tersebut, yang meliputi aktiva, kewajiban, ekuitas, pendapatan dan beban termasuk keuntungan dan kerugian, dan arus kas. Informasi tersebut beserta informasi lainnya yang terdapat dalam catatan atas laporan keuangan membantu 
INOBIS: Jurnal Inovasi Bisnis dan Manajemen Indonesia

Volume 1, Nomor 4, September 2018

Misti Hariasih; Rizal Yulianto; Amrin Hidayat

pengguna laporan keuangan dalam memprediksi arus kas pada masa depan, khususnya dalam hal waktu, dan kepastian diperolehnya kas dan setara kas (PSAK, 2002:Par. 1.2).

\section{Metode Penelitian}

Data yang diperoleh dalam penelitian ini akan dianalisis dengan mengggunakan analisis kuantitatif. karena dalam penelitian ini peneliti hanya akan mendeskripsikan data yang ada untuk memberikan gambaran tentang kondisi objek penelitian dan tidak bermaksud untuk menggeneralisasikan hasilnya. Lokasi penelitian ini bertempat di BPR Buduran Delta Purnama Sidoarjo.

\section{Definisi Operasional Variabel}

Adapun definisi operasional dalam penelitian ini adalah :

\section{Return On Asset (ROA)}

Berdasarkan Surat Edaran BI No. 6/23/DPNP tanggal 31 Mei 2004, Return On Assets (ROA) adalah rasio yang menilai seberapa tingkat pengembalian aset yang dimiliki. Sedangkan menurut Mardiyanto (2009:196), "ROA adalah rasio yang digunakan untuk mengukur kemampuan perusahaan dalam menghasilkan laba yang berasal dari aktivitas investasi”.

ROA merupakan rasio yang digunakan dalam mengukur kinerja keuangan perbankan. Menurut Surat Edaran BI No. 3/30DPNP tanggal 14 Desember 2001, ROA dapat dihitung dengan rumus sebagai berikut:

$$
\text { ROA }=\frac{\text { Laba Bersih Setelah Pajak }}{\text { Total Aktiva }} \times 100 \%
$$

Laba sebelum pajak adalah laba bersih dari kegiatan operasional bank sebelum pajak. Total aset yang digunakan untuk mengukur ROA adalah jumlah seluruh dari aset yang dimiliki oleh bank bersangkutan.

\section{Non Performing Loan (NPL)}

Non Performing Loan (NPL) adalah kredit bermasalah yang terdiri dari kredit yang berklasifikasi Kurang Lancar, Diragukan dan Macet. Rasio ini menunjukan bahwa kemampuan manajemen bpr dalam mengelola pembiayaan bermasalah yang diberikan oleh bpr sehingga semakin tinggi rasio ini maka semakin buruk kualitas pembiayaan bpr tersebut..

\section{Beban Operasional terhadap Pendapatan Operasional (BOPO)}

Beban operasional merupakan beban-beban yang dikeluarkan perusahaan pada saat menjalankan kegiatan pokok, seperti beban bunga, beban tenaga kerja,beban pemasaran dan beban lainnya. Pendapatan operasional adalah pendapatan utama yang diperoleh dari penempatan dana dalam bentuk kredit dan penempatan operasi lainnya. Jika rasio BOPO rendah berarti biaya operasional yang dikeluarkan oleh perusahaan semakin efisien dan memberikan kesempatan untuk memperoleh laba yang lebih tinggi (Restiyana, 2011). 
INOBIS: Jurnal Inovasi Bisnis dan Manajemen Indonesia

Volume 1, Nomor 4, September 2018

Misti Hariasih; Rizal Yulianto; Amrin Hidayat

"Rasio BOPO digunakan untuk mengukur tingkat efisiensi dan kemampuan bank dalam melakukan kegiatan operasionalnya", (Dendawijaya, 2009:120). Berdasarkan Surat Edaran Bank Indonesia No. No.13/30/DPNP tanggal 16 Desember 2011 untuk mengukur BOPO dapat dirumuskan sebagai berikut:

$$
B O P O=\frac{\text { Total Beban Operasional }}{\text { Total Pendapatan Operasional }} \times 100 \%
$$

\section{Hasil dan Pembahasan}

\section{Analisis regresi linier berganda}

Regresi linier berganda bertujuan untuk mengetahui bagaimana pengaruh variabel independen yakni risiko kredit dan efisiensi operasional terhadap variabel dependen yakni kinerja keuangan bank. Adapun hasil regresi linear berganda pengaruh variabel risiko kredit dan efisiensi operasional terhadap kinerja keuangan bank di Bursa Efek Indonesia (BEI) adalah sebagai berikut:

\section{Tabel 6. Hasil Regresi Linear Berganda}

\begin{tabular}{|l|r|r|r|}
\hline \multirow{2}{*}{ Model } & \multicolumn{2}{|c|}{$\begin{array}{c}\text { Unstandardized } \\
\text { Coefficients }\end{array}$} & $\begin{array}{c}\text { Standardized } \\
\text { Coefficients }\end{array}$ \\
\cline { 2 - 4 } & \multicolumn{1}{|c|}{ B } & Std. Error & \multicolumn{1}{c|}{ Beta } \\
\hline 1 (Constant) & 2.875 & .723 & \\
NPF & -.314 & .075 & -.610 \\
BOPO & -.014 & .009 & -.222 \\
\hline
\end{tabular}

Dari tabel di atas dapat dirumuskan suatu persamaan regresi seperti berikut:

$$
Y=2.875-0,314 \times 1-0,014 \times 2
$$

Keterangan :

$$
\mathrm{Y}=\mathrm{ROA}
$$

$\mathrm{X} 1=\mathrm{NPF}$

$\mathrm{X} 2=\mathrm{BOPO}$

$\mathrm{a}=$ Konstanta

$\mathrm{e}=$ Standart Eror

Persamaan regresi tersebut menjelaskan besar dan arah pengaruh dari masing-masing variabel bebas terhadap variabel terikatnya. Dari persamaan regresi yang telah ada, maka diketahui variabel risiko kredit dan efisiensi operasional yang sama-sama memiliki tanda negatif berarti risiko kredit dan efisiensi operasional memiliki pengaruh yang berlawanan arah dengan 
INOBIS: Jurnal Inovasi Bisnis dan Manajemen Indonesia

Volume 1, Nomor 4, September 2018

Misti Hariasih; Rizal Yulianto; Amrin Hidayat

kinerja keuangan bpr. Berdasarkan persamaan tersebut, maka dapat dijelaskan arti dari masingmasing koefisien tersebut sebagai berikut:

1. Koefisien regresi variabel $N P L(\mathrm{X} 1)$ adalah sebesar -0,314 menunjukkan bahwa variabel $N P L$ jika meningkat satu maka variabel $N P L$ ) akan mengalami penurunan sebesar $-0,314$ dengan ketentuan variabel lainya memiliki nilai tetap atau konstan. Koefisian bernilai negatif menunjukkan terjadi hubungan yang berlawanan. Artinya setiap kenaikan NPL akan diikuti oleh penurunan Return On Asset dan sebaliknya setiap penurunan NPL akan diikuti oleh kenaikan Return On Asset.

2. Koefisien regresi variabel BOPO (X2) adalah sebesar -0,014 menunjukkan bahwa variabel BOPO jika meningkat satu maka variabel BOPO akan mengalami penurunan sebesar 0,014 dengan ketentuan variabel lainya memiliki nilai tetap atau konstan. Koefisian bernilai negatif menunjukkan terjadi hubungan yang berlawanan. Artinya setiap kenaikan BOPO akan diikuti oleh penurunan Return On Asset dan sebaliknya setiap penurunan BOPO akan diikuti oleh kenaikan Return On Asset.

\section{Pengujian Hipotesis}

\section{a. Uji Statistik F (Simultan)}

Uji F digunakan untuk mengetahui apakah variabel independen (risiko kredit dan efisiensi operasional) yang digunakan dalam persamaan regresi secara bersama sama memiliki pengaruh terhadap variabel dependen (kinerja keuangan). Hasil uji statistik F (simultan) dalam penelitian ini adalah sebagai berikut:

Tabel 7

\section{Hasil Uji Statistik F (Simultan)}

\begin{tabular}{|l|r|r|r|r|r|}
\hline Model & \multicolumn{1}{|c|}{$\begin{array}{c}\text { Sum of } \\
\text { Squares }\end{array}$} & Df & \multicolumn{1}{c|}{$\begin{array}{c}\text { Mean } \\
\text { Square }\end{array}$} & \multicolumn{1}{c|}{ F } & Sig. \\
\hline Regression & 7.458 & 2 & 3.729 & 15.719 & $.000^{\mathrm{a}}$ \\
Residual & 6.405 & 27 & .237 & & \\
Total & 13.863 & 29 & & & \\
\hline
\end{tabular}

Sumber : data sekunder di olah

Dapat dilihat dari tabel hasil uji statistik F (simultan) di atas menujukan bahwa model persamaan yang digunakan memiliki $F$ hitung sebesar 15,719 dengan tingkat signifikan 0,000. Hal ini berarti nilai $\mathrm{F}$ hitung lebih besar dari nilai $\mathrm{F}$ tabel $(15,719>3,3541)$ dan tingkat signifikan lebih kecil dari taraf signifikan $(0,000<0,05)$ Maka dapat disimpulkan bahwa secara bersama sama variabel NPL dan BOPO berpengaruh terhadap Return On Asset.

b. Uji Statistik T (Parsial)

Uji statistik t pada dasarnya menunjukan seberapa jauh pengaruh satu variabel independen ( $N$ dan BOPO) secara individual menerangkan variasi variabel dependen (Return On Asset). Hasil uji statistik t (parsial) dalam penelitian ini adalah sebagai berikut: 
INOBIS: Jurnal Inovasi Bisnis dan Manajemen Indonesia

Volume 1, Nomor 4, September 2018

Misti Hariasih; Rizal Yulianto; Amrin Hidayat

Tabel 8. Hasil Uji Statistik t (Parsial)

\begin{tabular}{|l|r|r|r|r|r|}
\hline \multirow{2}{*}{ Model } & \multicolumn{2}{|c|}{$\begin{array}{c}\text { Unstandardized } \\
\text { Coefficients }\end{array}$} & $\begin{array}{c}\text { Standardized } \\
\text { Coefficients }\end{array}$ & & \\
\cline { 2 - 5 } & \multicolumn{1}{|c|}{ B } & \multicolumn{1}{c|}{$\begin{array}{c}\text { Std. } \\
\text { Error }\end{array}$} & \multicolumn{1}{|c|}{ Beta } & \multicolumn{1}{c|}{ T } & Sig. \\
\hline 1 (Constant) & 2.875 & .723 & & 3.977 & .000 \\
NPF & -.314 & .075 & -.610 & -4.214 & .000 \\
BOPO & -.014 & .009 & -.222 & -1.534 & .137 \\
\hline
\end{tabular}

Sumber : data sekunder di olah

Dengan menggunakan tingkat kepercayaan sebesar 5\% $(\alpha=0,05)$ dan degree of freedom (df) 27 diperoleh $t_{\text {tabel }}$ sebesar 1,703, maka dapat disimpulkan :

1. Hasil uji statistik $\mathrm{t}$ di atas menunjukan bahwa variabel $N P L$ memiliki nilai sig. Sebesar $0,000<0,05$ maka $\mathrm{H} 0$ ditolak dan $\mathrm{H}_{1}$ diterima, dan diperoleh $\mathrm{t}_{\text {hitung }}$ sebesar -4.214 dan $\mathrm{t}_{\text {tabel }}$ sebesar 1,703 sehingga dapat diartikan bahwa terdapat pengaruh yang signifikan dan berpengaruh negatif NPL terhadap Return On Asset.

2. Hasil uji statistik $t$ di atas menunjukan bahwa variabel BOPO memiliki nilai sig. Sebesar 0,137>0,05 maka $\mathrm{H}_{0}$ diterima dan $\mathrm{H}_{1}$ ditolak, dan diperoleh $\mathrm{t}_{\text {hitung }}$ sebesar -1.534 dan $\mathrm{t}_{\text {tabel }}$ sebesar 1,703 sehingga dapat diartikan bahwa tidak terdapat pengaruh yang signifikan variabel BOPO terhadap Return On Asset.

c. Koefisien Determinan $\left(\mathrm{R}^{2}\right)$

Nilai $\mathrm{R}$ square $\left(\mathrm{R}^{2}\right)$ atau Koefisien determinan digunakan untuk mengukur seberapa jauh kemampuan variabel independen risiko kredit dan efisiensi operasional dalam menjelaskan variasi yang terjadi dalam variabel dependen kinerja keuangan dapat diketahui dari besarnya nilai koefisien determinan atau $R$ Square $\left(\mathrm{R}^{2}\right)$. Hasil koefisien determinasi dalam penelitian ini adalah sebagi berikut:

\section{Tabel 9}

Hasil Koefisien Determinan $\left(\mathbf{R}^{2}\right)$

\begin{tabular}{|l|c|r|r|c|}
\hline Model & $\mathrm{R}$ & R Square & $\begin{array}{c}\text { Adjusted R } \\
\text { Square }\end{array}$ & $\begin{array}{c}\text { Std. Error of the } \\
\text { Estimate }\end{array}$ \\
\hline 1 & $.733^{\mathrm{a}}$ & .538 & .504 & \multicolumn{1}{c|}{.48705} \\
\hline
\end{tabular}

Sumber : data sekunder di olah

Hasil Koefisien determinan pada tabel di atas menunjukan bahwa nilai R Square adalah sebesar 0,538 atau 53\% yang artinya bahwa variabel dependen mampu dijelaskan oleh variabel independen sebesar 53\%. Dengan kata lain 53\% Kinerja keuangan mampu dijelaskan variabel risiko kredit dan variabel efisiensi operasional, sedangkan $47 \%$ dijelaskan oleh variabel atau faktor lain di luar model yang digunakan dalam penelitian ini. 
INOBIS: Jurnal Inovasi Bisnis dan Manajemen Indonesia

Volume 1, Nomor 4, September 2018

Misti Hariasih; Rizal Yulianto; Amrin Hidayat

\section{Pembahasan}

\section{a. Pengaruh risiko kredit terhadap kinerja keuangan}

Berdasarkan pengujian hipotesis yang telah dilakukan pada penelitian ini, maka secara statistik diperoleh hasil yang menunjukan bahwa variable risiko kredit berpengaruh negatif dan signifikan terhadap kinerja keuangan dengan nilai sig. Sebesar 0,000 < 0,05 maka dapat diartikan bahwa terdapat pengaruh yang signifikan dan berpengaruh negatif NPL terhadap Return On Asset

\section{b. Pengaruh efisiensi operasional terhadap kinerja keuangan}

Berdasarkan hasil statistik diperoleh hasil yang menunjukan bahwa efisiensi operasional terhadap kinerja keuangan tidak terdapat pengaruh yang signifikan dengan nilai sebesar sig. Sebesar 0,137>0,05 maka dapat diartikan bahwa tidak terdapat pengaruh yang signifikan variabel BOPO terhadap Return On Asset.

\section{c. Pengaruh risiko kredit dan efisiensi operasional terhadap kinerja keuangan}

Berdasarkan pengujian hipotesis yang telah dilakukan pada penelitian ini, maka secara statistik diperoleh hasil yang menunjukan bahwa variabel risiko kredit dan efisiensi operasional secara bersama-sama berpengaruh signifikan terhadap kinerja keuangan pada bpr dengan hasil statistik F hitung sebesar 15,719 dengan tingkat signifikan 0,000. Hal ini berarti nilai F hitung lebih besar dari nilai $\mathrm{F}$ tabel $(15,719>3,3541)$ dan tingkat signifikan lebih kecil dari taraf signifikan $(0,000<0,05)$ Maka dapat disimpulkan bahwa secara bersama - sama variabel $N P L$ dan BOPO berpengaruh terhadap Return On Asset.

\section{Simpulan dan Saran}

Berdasarkan hasil penelitian yang telah dilakukan tentang "Risiko kredit dan efisiensi operasional terhadap kinerja keuangan bpr konvensional" maka dapat disimpulkan: risiko kredit berpengaruh secara signifikan negatif terhadap kinerja keuangan bpr konvensional dan Efisiensi operasional tidak berpengaruh secara signifikan terhadap kinerja keuangan bpr konvensional sedangkan variabel risiko kredit dan efisiensi operasional secara bersama-sama atau simultan berpengaruh secara signifikan terhadap kinerja keuangan bpr konvensional, maka di harapkan risiko kredit macet di minimalisir agar kinerja keuangan bank itu sendiri tidak mengalami penurunan atau berpengaruh negatif terhadap kinerja keuangan.

\section{Referensi}

Capriani, Ni Wayan Wita dan Dana, I Made. 2016. Pengaruh Risiko Kredit, Risiko Operasional dan Risiko Likuiditas Terhadap Profitabilitas BPR Di Kota Denpasar. E-Jurnal Manajemen Unud, Vol. 5 No. (3) 1486-1512 ISSN: 2302-8912. Universitas Udayana Bali.

Masliana. 2011. Peran Dewan Pengawas Syariah (DPS) Dalam Pengawasan Pelaksanaan Kontrak Di Bank Syariah (Studi Pada Bank BRI Syariah). Program Strata-1 UIN Syarif Hidayatullah. Jakarta.

Peraturan Bank Indonesia Nomor. 11/25/PBI/2009 tentang Penerapan Manajemen Risiko Bagi Bank Umum. 
INOBIS: Jurnal Inovasi Bisnis dan Manajemen Indonesia

Volume 1, Nomor 4, September 2018

Misti Hariasih; Rizal Yulianto; Amrin Hidayat

Rosada, Nurhidayati. 2013. Analisis Pengaruh Rasio Keuangan Terhadap Kinerja Keuangan Pada PT. Bank Muamalat Indonesia Tbk. Jurnal ekonomi dan informasi akuntansi (Jenius). Vol. 3 No. (1). STIE-MURA Lubuklingau.

Sadi, Muhamad. 2015. Konsep Hukum Perbankan Syariah, Setara Press Kelompok Intrans Publishing Wisma Kalimetro, Jl. Joyosukometro 42 Malang, Jatim.

Saputra, I Made Hendra Edy dan Budiasih, I Gusti Ayu Nyoman. 2016. Pengaruh Kecakupan Modal, Risiko Kredit, Biaya Operasional Pendapatan Operasional Pada Profitabilitas Bank. E-Jurnal Akuntansi Universitas Udayana, Vol. 14 No. (3) ISSN: 2302-8559. Fakultas Ekonomi dan Bisnia Universitas Udayana.

Sudiyatno, Bambang dan Fatmawati, Asih. 2013. Pengaruh Risiko dan Efisiensi Operasional Terhadap Kinerja Bank (Studi Empirik pada Bank yang terdaftar di Bursa Efek Indonesia). Jurnal Organisasi dan Manajemen. Vol. 9 No. (1). Fakultas Ekonomi Universitas Stikubank Semarang.

Sugiyono. (2014). Metode Penelitian Bisnis, Cv Alfabeta, bandung.

Usman, Rahmadi. 2012. Aspek Hukum Perbankan Syariah di Indonesia, Sinar Grafika, Jl. Saworaya No. 18 Jakarta 13220.

Wibowo, Edhi Satriyo dan Syaichu, Muhammad. 2013. Analisis Pengaruh Suku Bunga, Inflasi, CAR, BOPO, NPF, Terhadap Profitabilitas Bank Syariah. Diponegoro Journal Of Management. Vol. 2 No. (2). Fakultas Ekonomi dan Bisnis Universitas Diponegoro.

Widyaningrum, Linda dan Septiarini, Dina Fitrisia. 2015. Pengaruh CAR, NPF, FDR, dan OER Terhadap ROA Pada Bank Pembiayaan Rakyat Syariah di Indonesia Periode Januari 2009 Hingga Mei 2014. JESTT Vol. 2 No. (12). Fakultas Ekonomi dan Bisnis Universitas Airlangga. 